\title{
REALITA BUDGET CONSTRAINT DAN TRADE-OFF SEBAGAI KONSEKUENSI BAGI PEMERINTAH DAERAH BALI DALAM PENGIMPLEMENTASIAN KEBIJAKAN DI MASA PANDEMI COVID-19
}

\author{
Oleh:
}

Deli Bunga Saravistha1 ; I Made Adi Widnyana² ; I Wayan Werasmana Sancaya ${ }^{3}$

E-mail: delisaravistha@gmail.com¹ ; widnyanamadeadi@gmail.com² :

wvimodc@gmail.com³

Universitas Mahendradatta

\begin{abstract}
The determination of a public policy is of course always faced with the problem of budget constraints which often puts the government in a trade-off situation which is defined as a dilemma condition that makes it difficult to make choices in determining priorities. This is what makes many policies that are not effectively implemented. The neglect of community expectations has resulted in negative reactions ranging from acts of violation even to anarchy that leads to crime. For this reason, it is deemed very important for the government to have a strategy in setting a priority scale so that a policy is more beneficial to people's lives, not just focusing on legal certainty. For this reason, the main problem is related to the efforts of the Regional Government in determining the priority scale so that an implementation of public policy is truly on target.
\end{abstract}

Keywords: Budget Constraint, Trade off, priority scale

\begin{abstract}
Abstrak
Penetapan suatu kebijakan publik tentunya selalu dihadapkan dengan permasalahan keterbatasan anggaran (Budget Constraint) yang kerap kali menempatkan pemerintah dalam situasi Trade-Off yang diartikan sebagai kondisi dilematis yang membuat adanya pilihan sulit dalam menentukan prioritas. Hal ini lah yang membuat banyaknya kebijakan yang tidak efektif diterapkan. Terabaikannya ekspektasi komunitas membuat reaksi negatif mulai dari aksi pelanggaran bahkan hingga anarkis yang berujung kriminal. Untuk itu dirasa sangat penting strategi bagi pemerintah dalam menetapkan suatu skala prioritas agar suatu kebijakan lebih bermanfaat bagi kehidupan masyarakat bukan hanya fokus pada kepastian hukum semata. Untuk itu pokok permasalahan terkait Upaya Pemerintah Daerah dalam menentukan skala prioritas agar suatu implementasi kebijakan publik benar-benar tepat sasaran.
\end{abstract}

Kata Kunci: Budget Constraint, Trade off, Skala Prioritas.

\section{PENDAHULUAN}

Pada 11 Maret 2020 World Health Organization/WHO mengumumkan bahwa dunia sedang dilanda pandemi yaitu COVID19 (Corona Virus Disease 2019). Di banyak media masa bahkan elektronik
Presiden Jokowi menyatakan agar di seluruh negeri diterapkan Pembatasan Sosial Berskala Besar atau PSBB yang didasari atas Undang-Undang Nomor 6 Tahun 2018 tentang Karantina Wilayah sebagai landasan hukumnya. Undang-Undang Nomor 4 
Realita Budget Constraint Dan Trade-Off Sebagai Konsekuensi Bagi Pemerintah Daerah Bali Dalam Pengimplementasian Kebijakan Di Masa Pandemi Covid19 (Deli Bunga, dkk., 199-206)

Tahun 1984 tentang Wabah Penyakit menular dan Undang-Undang Nomor 24 tahun 2007 tentang Penanggulangan Bencana. Selanjutnya ditetapkan Peraturan Pemerintah Nomor 21 Tahun 2020 (selanjutnya disebut "PP 21/2020") sebagai peraturan pelaksanaan dari PSBB ini (Alit, 2021). PP 21/2020 ini ditetapkan oleh Menteri Kesehatan dan dapat dilaksanakan oleh Pemerintah Daerah melalui Gubernur berdasarkan atas persetujuan dari Menteri. Diatur juga dalam ketentuan Pasal 5 Ayat (1) dan (2) UU 6/2018.

Terkait teknisnya baik sarana dan prasarana dan khususnya perihal sumber daya adalah menjadi tanggung jawab pemerintah pusat dan daerah. Hal ini tentu ada kaitannya dengan urusan anggaran pemerintah. Berbicara soal anggaran tentu saja jumlahnya pasti terbatas, maka sangat penting untuk memikirkan strategi matang di dalam setiap kebijakan pemerintah yang dikeluarkan, dimana kebijakan ini tentunya adalah ditujukan untuk kebaikan masyarakat. Dalam suatu kebijakan pasti sudah dirancang program-program di dalamnya, disinilah peranan penting adanya strategi, agar program-program tersebut dapat dilaksanakan dengan sebaik-baiknya. Jika tidak, maka terkait dengan keterbatasan anggaran atau Budget Constraint akan dapat menimbulkan lost of opportunity.

Hilangnya kesempatan yang dimaksud adalah akibat strategi kebijakan yang kurang tepat. Di dalam setiap penetapan sebuah kebijakan, pemerintah selalu akan dihadapkan pada situasi trade-off, yang artinya untuk merancang suatu program maka tidak mungkin merangkul keseluruhan dari isu yang ada atau akan mungkin ada/muncul belakangan di masyarakat (Erwan, p.5, 2015) Pemerintah akan selalu dihadapkan pada pertukaran dimana kondisi dilematis yang mengharuskan dilakukannya pemilihan tersebut mengingat adanya realita keterbatasan anggaran. Dalam hal ini pemerintah harus berhati-hati dalam menentukan strategi kebijakannya. Agar anggaran pemerintah tidak siasia dan lebih tepat sasaran dalam penggunaannya. Sebagai contoh misalnya saat pemerintah daerah menerapkan kebijakan PKM (Pembatasan Kegiatan Masyarakat) dengan membuat pos-pos penjagaan ketat di setiap perbatasan dengan sarana dan prasarana terkait untuk itu di dalamnya. Dengan mengadakan kebijakan tersebut pemerintah mengabaikan kenyataan tentang banyaknya masyarakat yang kehilangan pekerjaan dan tidak produktif selama PKM berlangsung berada di situasi sangat kesulitan ekonomi bahkan hanya sekedar untuk makanpun jadi sangat sulit.

Pada tanggal 26 Maret 2020 lalu sejak Hari Raya Nyepi berlangsung pemerintah Daerah Bali telah melakukan lockdown awal dengan menambah hari Nyepi satu hari lagi. Seiring berjalannya waktu, kemerosotan yang terjadi malah semakin parah. Bali yang merupakan daerah pariwisata mengalami fase penurunan. Tidak ada wisatawan datang ke Bali sebanyak biasanya, sangat jauh merosot. Bahkan bukan Bali saja tapi ini dialami hampir seluruh dunia.

Kehilangan mata pencaharian memberi dampak negatif yang tidak hanya sebatas susah makan, tapi masyarakat mulai mengalami frustasi. Kasus bunuh diri mulai bermunculan sebagai bukti dari keputusasaan individu masyarakat dan hal ini pastinya akan berimbas pada pola kehidupan sosial masyarakat secara menyeluruh (Suratman, dkk, 2019). Banyak warga sipil yang tidak paham 
bahwa mereka adalah orang yang berhak menerima bantuan dari pemerintah, bahkan tidak tahu. Adapun yang mengetahui akan tetap dihadapkan pada proses birokrasi yang rumit, Sementara data yang dilaporkan ke pusat adalah data yang sarat muatan politik agar kinerja pemerintah daerah nampak baik mengatasi pandemi.

\section{Kurangnya}

keterbukaan

pemerintah pada masyarakat justru menimbulkan ketakutan berlebihan. Tidak jelas jumlah korbannya, belum jelas kasusnya lalu beberapa wilayah mulai melakukan karantina mandiri dengan mengisolasi wilayahnya secara agak berlebihan. Padahal untuk melakukan PSBB maka jumlah kasus dan/atau kematian akibat penyakit meningkat dan menyebar secara signifikan dan cepat ke wilayah tersebut dan sekitarnya. Kemudian harus terdapat kaitan epidemiologis dengan kejadian serupa di wilayah atau negara lain, maksudnya memenuhi kriteria bahwa benar ada yang positif terjangkit virus ini. Namun, yang terjadi adalah setiap orang yang sakit atau setiap adanya kematian di suatu wilayah lantas membuat kepanikan dan memvonis yang bersangkutan terjangkit COVID19.

Harus betul-betul dikerahkan tenaga ahli kesehatan untuk memastikan hal tersebut, karena tidak ada virus pandemi ini pun orang sakit dan kematian itu adalah hal yang selalu akan ada. Krisis kepercayaan mulai bermunculan, karena beritaberita mulai memuat hal-hal konyol semisal satu desa yang divonis positif COVID19 lalu diisolasi, kemudian setelah dilakukan pengecekan ulang diperoleh bahwa alat kesehatan yang digunakan sebelumnya rusak/bermasalah. Program pengecekan kesehatan masyarakat yang diinstruksikan Bapak Presiden bukan lelucon yang main-main. Bukan pula ajang bisnis untuk dimanfaatkan oleh beberapa oknum meraih keuntungan.

Pengadaan barang dan jasa yang tidak sesuai itu sudah membuat negara rugi. Membuat masyarakat semakin panik dan frustasi, dan mulai menyangsikan kebijakan pemerintah. Lalu hal penting lain adalah seharusnya alokasi dana untuk membeli alat baru dan melakukan tes ulang itu bisa digunakan untuk hal lain seperti mengadakan bantuan bahan pangan, sektor pendidikan dan program penting lain yang nyata-nyata jauh lebih dibutuhkan oleh masyarakat ketimbang protokol yang ketat namun tidak diikuti dengan solusi ekonomi.

Ketidakcermatan pemerintah daerah dalam menentukan skala prioritas dalam proses formulasi kebijakannya sangat menarik untuk dibahas agar nantinya setidaknya dapat memberikan suatu rekomendasi terhadap upaya reformulasi ke depannya. Hal ini akan dikaitkan dengan budget constraint yang sedikit memaksa pemerintah untuk memahami pentingnya menentukan skala prioritas dalam setiap pembentukan kebijakan pemerintah. Penulisan ini mengacu pada dua pokok permasalahan yaitu terkait Upaya Pemerintah Daerah dalam menentukan skala prioritas agar suatu implementasi kebijakan publik benarbenar tepat sasaran.

\section{METODE}

Penelitian ini menggunakan metode penelitian yuridis sosiologis yang mengkaji perilaku masyarakat (Mukti F, 2013). Dimana yang dimaksud dengan perilaku masyarakat adalah perilaku atau pola yang timbul akibat berinteraksi dengan sistem norma yang ada. Namun, penelitian yuridis sosiologis bukan ingin memberikan justifikasi hukum layaknya pada penelitian normatif, penelitian ini hanya 
Realita Budget Constraint Dan Trade-Off Sebagai Konsekuensi Bagi Pemerintah Daerah Bali Dalam Pengimplementasian Kebijakan Di Masa Pandemi Covid19

sebatas memaparkan fakta-fakta sosial secara sistematis.

\section{PEMBAHASAN}

1. Konsep Welfare State, Budget Constraint, dan Trade-off dalam Setiap Formulasi dan Konstruksi Kebijakan Pemerintah

Dalam konsep negara kesejahteraan, negara tidak dapat lepas dari tanggung jawab mengatasi dan menangani setiap permasalahan terkait kesejahteraan masyarakatnya. Negara adalah penanggung jawab terhadap tujuan utama penganut konsep ini yaitu meningkatkan kesejahteraan masyarakatnya bukan sebatas kekuasaan yang cenderung abuse of power (Deli, 2021). Soepomo mengaitkan konsep walfare state dengan paham negara integral yang memiliki pengertian bahwa negara adalah segalanya dan tidak berdiri sendiri di atas sebagian golongan tetapi untuk seluruh rakyat dan menjamin keselamatan hidup setiap warga negaranya (Enny, 2019). Ide ini tertuang dalam konstitusi yaitu alinea keempat UUD 1945. Sehingga dalam kaitannya dengan pencapaian konsep ini dibentuklah sistem pemerintahan yang berfungsi mengejawantahkan cara-cara mencapai tujuan tersebut.

Penyelenggaraan negara yang didasari konsep ini akan banyak menerapkan asas diskresi sehingga akan memperluas perbuatan pemerintah sampai kepada pelaksanaan fungsi perundangundangan. Pelaksanaan yang dimaksudkan disini adalah membentuk bebagai peraturan mulai dari undangundang, peraturan pemerintah hingga peraturan daerah. Bahkan, sampai kepada perumusan kebijakan publik sebagai realisasi tindakan untuk mencapai tujuan utama dalam suatu peraturan dibentuk dan diimplementasikan. Dalam konteks pemerintah daerah, dimana urusan pemerintahan di level ini merupakan kompetensi otonomi daerah yang kemudian dimanifestasikan ke dalam bentuk pelayanan publik bagi masyarakat dengan semangat walfare state sesuai amanat UUD 1945.

Jangan sampai, kebijakan pemerintah daerah justru memberi kesengsaraan dan permasalahan- permasalahan baru. Anggaran yang ada tentunya terbatas. Keterbatasan anggaran pemerintah inilah yang dalam istilah public policy disebut dengan istilah Budget Constraint. Dari sekian kebijakan pemerintah, fakta menunjukkan bahwa lebih banyak kebijakan yang efektifitasnya cenderung menemui kegagalan ketimbang keberhasilan. Kegagalan ini berdampak pada kerugian finansial negara terkait keterbatasan anggaran pemerintah. Sehingga dalam pilihan kebijakan yang diambil oleh pemerintah selalu menyebabkan terjadinya pertukaran atau trade-off. Pemerintah akan memilih isu yang dirasa paling penting untuk didahulukan dan sementara mengabaikan persoalan yang lain.

2. Kriteria Penetapan Skala Prioritas dalam Formulasi Kebijakan Pemerintah dan Konstruksi Program yang Baik terkait Pandemi Covid19 dan Kebijakan New Normal Memberi penilaian atas keberhasilan atau kegagalan suatu implementasi, ada enam variabel penting, antara lain terkait tujuan atau sasaran kebijakan yang jelas dan konsisten, dukungan teori yang kuat dalam proses perumusannya, proses implementasi memiliki dasar hukum yang jelas sehingga menjamin terjadi kepatuhan para petugas di lapangan dan juga kelompok sasaran, komitmen dan keahlian para pelaksana kebijakan, dukungan para stakeholder, 
Stabilitas kondisi sosial, ekonomi, dan politik (Erwan, 2015).

Kondisi situasional yang kurang mendukung tentunya harus menjadi pertimbangan pemerintah dalam menyusun program di dalam kebijakan yang akan diterapkan. Pemerintah sebelum melakukan formulasi tentu dihadapkan pada trade off yang memaksa pemerintah berpikir dan memilah kemudian membijaksanai halhal yang sifatnya lebih patut diutamakan dari yang lain. Misalnya saja pilihan terhadap pengadaan pospos pemeriksaan di perbatasan wilayah dengan memberikan pengadaan bantuan bahan pokok dan pengecekan kesehatan rutin di tataran kelurahan atau bahkan banjar adat. Dari keduanya wajib dipertimbangkan yang mana yang sekiranya akan lebih efektif.

Dalam Legal System Theory yang dikemukakan oleh Lawrence $\mathrm{M}$. Friedman, terdapat tiga hal pokok terkait penerapan dan penegakkan hukum. Hal ini tentu juga sangat bisa diaplikasikan pada tataran kebijakan publik yang merupakan salah satu pengejawantahan atas norma hukum. Pertama, Legal Structure yang terdiri atas lembaga atau aparatur penegaknya yang bertanggung jawab untuk menerapkan suatu kebijakan publik. Kedua, Legal Substantie yang dalam hal ini adalah apa tujuan dan sasaran dari kebijakan yang diimplementasikan pemerintah daerah tersebut termasuk juga terkait program-program di dalamnya. Terakhir adalah Legal Culture atau budaya masyarakat merespon suatu kebijakan yang diterapkan. Bukan hanya sebatas itu, melainkan juga termasuk budaya seluruh aktor yang terlibat di dalamnya yaitu pemerintah, aparatur beserta jajarannya. Ketiga hal itu adalah faktor yang paling menentukan dalam efektifitas sebuah peraturan atau kebijakan publik.
Dalam konteks efektifitas hukum atau suatu kebijakan struktur hukum, substansi hukum dan budaya hukum tersebut bukanlah merupakan hal yang dikotomi, ataupun dapat dipandang sebagai subsistem. Ketiga hal tersebut harus dipandang sebagai satu kesatuan yang utuh (Lawrence, 2013).

Pandangan yang sama juga diungkapkan oleh Soerjono Soekanto bahwa efektifitas hukum akan dipengaruhi faktor produk hukum, penegak hukum, masyarakat, budaya dan sarana dan prasarana (H.Salim\&Erlies, 2013). Dari keseluruhan model formulasi kebijakan publik, secara teoritis model yang paling relevan digunakan adalah rational mode. Diantara model-model kebijakan yang ada, antara lain model rasional itu sendiri, model inkremental, model gabungan, model proses, model elit massa, model kelompok, model sistem dan model spekulasi, hanya model rasional yang mampu memiliki peluang keberhasilan dalam menyasar target kebijakan. Model rasional ini didasari oleh data-data lengkap yang menyeluruh yang sudah meliputi segisegi kehidupan yang terpenting diantara yang penting yang patut diperhatikan secara khusus. Data yang digunakan komprehensif karena dilakukan berdasarkan pertimbangan matang dari pengamatan dan riset mendalam selengkap-lengkapnya (Suratman dan Umi, 2019). Setelah data diperoleh, barulah pemerintah akan lebih mudah dalam menentukan skala prioritas seperti telah dikemukakan sebelumnya. Ketimbang menggunakan model spekulasi dan model lainnya yang lebih banyak peluang intervensi politik di dalamnya.

Salah satu faktor penting dalam efektifitas suatu kebijakan seperti telah dibahas di poin sebelumnya adalah budaya hukum. Jika tadi sudah dibahas mengenai budaya hukum aparatur penegaknya maka sekarang 
Realita Budget Constraint Dan Trade-Off Sebagai Konsekuensi Bagi Pemerintah Daerah Bali Dalam Pengimplementasian Kebijakan Di Masa Pandemi Covid19 (Deli Bunga, dkk., 199-206)

adalah mengupas mengenai peranan citizen participation. Hal ini dapat diartikan bahwa masyarakat secara luas haruslah menjadi aktor yang baik dalam merespon kebijakan yang dibuat oleh pemerintah daerah. Maka, harus disamakan persepsi antara tujuan kebijakan pemerintah daerah dengan perspektif masyarakat agar terjalin keselarasan satu sama lain. pentingnya strategi dan figur kepemimpinan pemerintah daerah. Untuk memberikan kekuatan pada suatu kebijakan leadership power sangat berperan. Terlebih lagi fakta bahwa sistem pemerintahan tidak mungkin lepas dari muatan politik, maka seorang figur pemimpin daerah haruslah kredibel dan memiliki wawasan terkait kebijakan publik. Kepercayaan dari masyarakat adalah faktor utama dalam menentukan leadership power tersebut (Susilo, 2017).

Kepercayaan dari masyarakat dapat diperoleh salah satunya dengan jalan melibatkan masyarakat secara langsung dalam setiap imlementasi kebijakan. Partisipasi ini bentuknya berupa direct participation, sebagai contoh di masa lockdown pandemi COVID19 dimana masyarakat yang paham mengenai fakta sosial bahwa sebagian dari mereka dalam kondisi kesulitan kebutuhan pokok. Akhirnya secara langsung melibatkan oknum masyarakat baik secara pribadi, lembaga, komunitas dan tokoh turun langsung ikut mengatasi hal tersebut dengan membagikan bahan kebutuhan pokok.

Jika melihat pada pola kehidupan masyarakat dengan menggunakan kacamata ilmu sosial dan antropologi Tidak ada satu orangpun yang memprediksi wabah apa yang akan terjadi di masa depan. Demikian dengan meledaknya wabah corona, tak ada yang bersiap sebelumnya, demikian tidak ada yang tahu apa yang harus dilakukan ketika serangan wabah mendera. Tak ada bidang keilmuan yang punya prediksi tepat apa yang mesti dilakukan dan bagaimana melakukannya. Pengetahuan mengajarkan kita banyak hal, tapi tidak memprediksi masa depan. Pengetahuan dimaksudkan untuk memperluas cara pandang kita pada suatu hal tertentu. Berbagai macam kejadian telah dilalui manusia dan kemanusiaan berdekadedekade ini. Pada jaman dahulu manusia akan menganggap bahwa suatu wabah adalah sebuah bentuk hukuman atau kemarahan dari para dewa, atau ia terjadi karena manusia melakukan suatu kesalahan. Sehingga jawaban dari sebuah wabah adalah sebuah permohonan maaf pada dewadewa yang marah itu. Hal itu masih dilakukan khususnya di masyarakat Bali, karena kepercayaan dan tradisi tradisional yang masih dipertahankan hingga kini.

Di Bali, umumnya ketika berhadapan dengan penyakit, masyarakat akan melakukan sekaligus dua hal yang bertentangan. Pada satu waktu ia mendatangi dokter untuk memeriksakan sakitnya, setelah itu ia akan mengunjungi shaman/dukun/balian yang juga ia percaya memiliki kemampuan untuk menyembuhkan penyakitnya. Hal semacam ini biasanya terjadi ketika seseorang menderita penyakit yang tak kunjung sembuh dalam waktu yang relatif lama. Hal serupa juga dilakukan pemerintah propinsi Bali dalam menghadapi wabah COVID19 melalui himbauan-himbauan yang bernuansa spiritual. Bukti nyatanya adalah dengan surat edaran dari masingmasing desa adat tentang banten/sarana upakara tertentu yang 
harus dipersembahkan oleh masyarakat adat.

Prediksi kesejarahan yang ditawarkan Yuval Noah Harari dalam Homo Deus: A brief history of tomorrow, menemukan tantangannya dalam konteks masyarakat seperti tersebut diatas. Secara singkat Yuval memaparkan seiring perjalanan waktu, orang-orang lebih banyak yang mati karena alasan politis dibandingkan kematian secara alami. Tidak terbayangkan ucapan Ignoran Marie Antoinette abad ke 18 lalu dijalankan pada abad ini.

Konteksnya sekarang melebar COVID19 menyerang hampir seluruh sudut dunia. Manusia dengan latar kultural yang berbeda menghadapi teror yang sama, demikian penanganannya (secara kultural) juga berbeda. Akan tetapi jika dicermati, secara esensial yang dilakukan adalah hal yang sama, respon pertama ketika pandemi ini menyerang adalah menghadapinya dengan kekuatan doa.

Respon selanjutnya memasuki dunia logika keilmuan, bahwa pandemi tidak akan berakhir hanya dengan doa, namun demikian permohonan keselamatan pada divine power tetap tidak berhenti, dan mungkin tidak akan pernah berhenti. Demikian mengandaikan tetap ada kekuatan yang tak terlihat yang mengatur tatanan dunia ini. Pada dasarnya manusia tidak (belum?) beranjak ke level selanjutnya, meminjam istilah Auguste Comte, kita masih pada metaphysical stage yang masih mempercayai kekuatan impersonal abstrak.

Lalu hal yang tidak disadari atau mungkin yang hanya disadari oleh sebagian kecil masyarakat bahwa kebijakan pemerintah melalui surat edaran desa adat justru semakin menambah beban ekonomi bagi mereka. Bagi sebagian masyarakat mengeluarkan cost untuk pengadaan sarana/sesajen upacara bukan masalah besar, tetapi akan menjadi masalah bagi kelompok masyarakat lainnya dan hal ini tidak bisa diabaikan oleh pemerintah.

Perlu disosialisasikan kepada masyarakat, agar bagi yang menemui kesulitan baik kebutuhan pokok ataukah dalam hal menjalankan isi surat edaran yang dimaksud diatas, untuk menyampaikan kesulitannya kepada pemerintah melalui tokoh atau wakil-wakil dari desa adat/dinas. Tentu saja, sosialisasinya bisa dilakukan kerumah-rumah dalam bentuk surat edaran juga. Jadi, surat edaran tidak hanya memberikan semacam kewajiban baru untuk melakukan hal tertentu, melainkan sekaligus memberikan solusi bagi yang menemui kendala dalam pelaksanaannya. Hal ini tentu harus dipikirkan, apalagi hal tersebut dilakukan dengan alasan mempertahankan tradisi/taksu di Bali.

\section{PENUTUP}

Melihat adanya realitas keterbatasan anggaran/ Budget Constraint di dalam setiap kebijakan pemerintah, perlu diadakan strategi khusus untuk menentukan skala prioritas yang tepat sasaran yang dapat dilakukan dengan citizen participation untuk menghasilkan rekomendasi bagi proses evaluasi kebijakan lebih sempurna, skala prioritas yang lebih aktual karena langsung bersumber dari aspirasi masyarakat. Masyarakat Bali adalah masyarakat komunal yang masih sangat kental dengan tradisi budaya. Namun, dalam kaitannya dengan kebijakan pemerintah dalam penanganan COVID19 perlu juga dipertimbangkan permasalahan yang lebih utama dan nyata-nyata dihadapi oleh masyarakat terdampak COVID19, salah satunya kesulitan ekonomi. Sehingga, kebijakan pemerintah 
Realita Budget Constraint Dan Trade-Off Sebagai Konsekuensi Bagi Pemerintah Daerah Bali Dalam Pengimplementasian Kebijakan Di Masa Pandemi Covid19 (Deli Bunga, dkk., 199-206)

daerah melalui surat edaran yang pernah disebar melalui desa adat harus juga mempertimbangkan solusi ekonomi bagi kelompok masyarakat yang dalam kondisi situasional sangat sulit ekonomi. Begitupun dengan kebijakan new normal dan kebijakan penerapan protokol kesehatan, bagi sebagian kelompok masyarakat tentu memenuhi standar protokol kesehatan yang diwajibkan pemerintah tidak jadi masalah. Namun, untuk masyarakat kecil akan menjadi masalah baru. Dengan adanya keterlibatan masyarakat dalam setiap kebijakan, maka materi evaluasi akan lebih realistis dan lebih sesuai dengan kebutuhan masyarakat sesungguhnya, sehingga Trade-off yang selalu menempatkan pemerintah daerah dalam situasi dilematis, dapat tersolusikan dengan baik.

\section{DAFTAR PUSTAKA}

Banjarnahor, Daulat Nathanael dkk, 2021, Ilmu Negara, Bandung, Widina Bhakti Persada Bandung

Dr. H. Suratman, dkk, 2019, Hukum dan Kebijakan Publik, Bandung, PT. Refika Aditama

Erwan Agus Purwanto dan Dyah Ratih Sulistyastuti, 2015, Implementasi Kebijakan Publik (Konsep dan Aplikasinya di Indonesia), Yogyakarta, Gava Media

Enny Nurbaningsih, 2019, Problematika Pembentukan Peraturan Daerah, Jakarta, PT. Raja Grafindo Persada

Fajar ND, Mukti dan Achmad, Yulianto, 2013, Dualisme Penelitian Hukum Normatif dan Empiris, Yogyakarta: Pustaka Pelajar.
H. Salim HS dan Erlies Septiana Nurbani, 2013, Penerapan Teori Hukum Pada Penelitian Tesis dan Disertasi, Jakarta, Raja Grafindo Persada

H. Suratman, Hayat, dan Hj. Umi Salamah, 2019, Hukum dan Kebijakan Publik, Bandung, Refika Aditama

Lawrence M. Friedman, 2013, Sistem Hukum Perspektif Ilmu Sosial, Bandung, Nusa media

Putrawan, I Nyoman Alit, 2021, Jurnal Vyavahara Duta Vol XVI, No.1, Maret 2021: Penerapan PSBB Di Kota Denpasar Dalam Mengantisipasi COVID-19

Handoyo, Susilo, 2017, Jurnal De Facto Vol.4 No.2 : Efektifitas Hukum Terhadap Kepatuhan Perusahaan Dalam Kepersertaan BPJS Kesehatan, https://doi.org/10.36277/jurnaldef acto.v4i2.47 